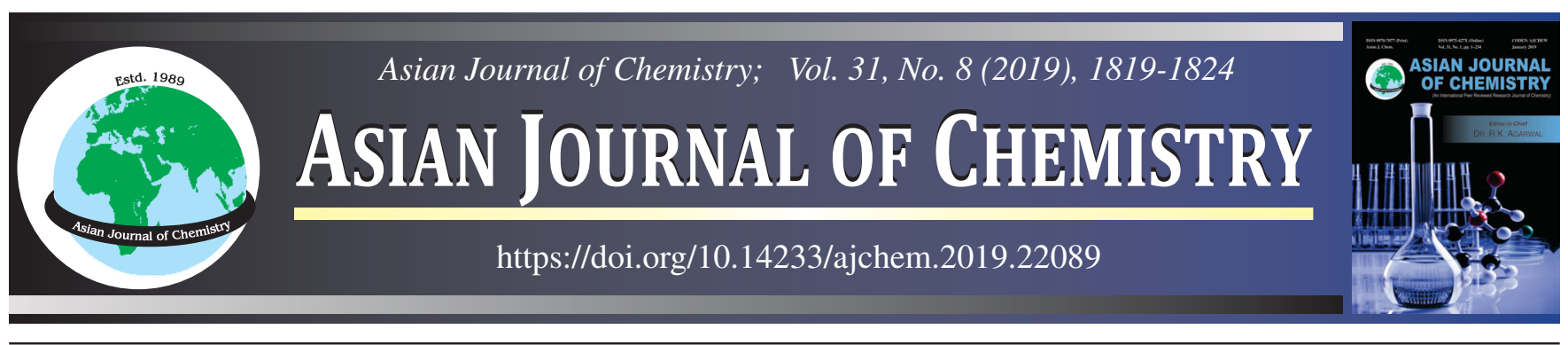

\title{
Synthesis, Characterization and Antifungal Studies of Adducts of $p$-Ethylphenyldithiocarbonates of Copper(II)
}

\author{
Shivangi Sharma ${ }^{1, *}$, Renu Sachar $^{1}$, G.D. BajuU ${ }^{1}$ and Vikas Sharma ${ }^{2}$
}

${ }^{1}$ Department of Chemistry, University of Jammu, Baba Saheb Ambedkar Road, Jammu-180006, India

${ }^{2}$ Division of Biochemistry, Faculty of Basic Sciences, Sher-e-Kashmir University of Agricultural Sciences and Technology of Jammu, Main Campus Chatha, Jammu-180009, India

*Corresponding author: Tel: +91 9622396568; E-mail: sharmashivangi8618@gmail.com

A series of adducts of $p$-ethylphenyldithiocarbonates of copper(II) $\left[\left(p-\mathrm{C}_{2} \mathrm{H}_{5} \mathrm{C}_{6} \mathrm{H}_{4} \mathrm{OCS}\right)_{2} \mathrm{Cu}\right]$ with ethyl pyridines and chloro pyridines have been synthesized in 1:2 molar ratio. They were characterized by elemental analysis, magnetic susceptibility and molar conductance measurements, infrared, electronic, electron spin resonance and mass spectroscopy, NMR and thermogravimetric analysis. In addition, antifungal studies of these adducts were also performed. The results revealed that the adducts have 1:2 stoichiometry, non-electrolytic and paramagnetic at room temperature. On the basis of spectral studies, a distorted octahedral geometry is proposed around copper(II) ion. ESR studies depicted elongated axial symmetry of $\mathrm{Cu}(\mathrm{II})$ adducts with nitrogen donors. Moreover, the adducts also showed potential antifungal activity against Fusarium oxysporium.

Keywords: Dithiocarbonates, Pyridines, Octahedral, Antifungal.

ᄂ

\section{INTRODUCTION}

Dithiocarbonates, commonly known as xanthates (xanthous ${ }^{\mathrm{G}}$ = yellowish golden) are salts \& ester of xanthic acid $\mathrm{ROC}(=\mathrm{S}) \mathrm{SH}$ ( $\mathrm{R}=$ alkyl or aryl), obtained by reaction of an alcohol with sodium or potassium hydroxide and carbon disulphide. Xanthates of a large number of coordination complexes of transition and main group metals are known [1]. It has been reported that metal aryl xanthates has been successfully formed by reacting carbon disulphide with phenol in presence of metal $[2,3]$. Alkyldithiocarbonates were first prepared by Semeniuc et al. [4] and Andotra et al. [5]. It has been reported from a long time that dithiocarbonates are being used in the vulcanization of rubber [6], manufacturing of synthetic textiles and as fungicides [7], metalloenzymes, material precursors, flotation reagents in metallurgy and as catalysts [8-10]. Xanthates show a number of coordination modes. They can coordinate to metal in a monodentate, isobidentate or anisobidentate fashion [11-14]. Xanthates of metals have also been successfully used in preventing corrosion, as pharmaceuticals, pesticides and fungicides in agricultural processes and in treating HIV infections [15-
19]. Certain metal xanthates were also known to be potent antiviral and antitumor agents [20,21].

Copper is an essential trace element present in the body of living organisms. Copper is essential metal for living organisms because of its use in various enzyme systems, proteins and due to its enhanced synergistic effect with drugs [22]. Copper(II) forms complexes with drugs as ligands, which exhibits increased activity when compared to free drugs [23] and some complexes of copper(II) xanthate with different ligands are found to be potent antitumor [24,25] and antioxidant [26,27] agents. Presently, we are reporting the synthesis of $p$-ethylphenyldithiocarbonates of copper(II) with ethyl pyridines and chloro pyridines and their characterization by different physico-chemical and spectroscopic techniques.

\section{EXPERIMENTAL}

Sodium salts of $p$-ethylphenyldithiocarbonates were prepared using standard protocol [28]. Toluene and $n$-hexane were freshly dried over sodium wire. Dichloromethane and methanol were dried over $\mathrm{P}_{2} \mathrm{O}_{5}$ and $\mathrm{CaCO}_{3}$, respectively. $p$-Ethylphenol

This is an open access journal, and articles are distributed under the terms of the Attribution 4.0 International (CC BY 4.0) License. This license lets others distribute, remix, tweak, and build upon your work, even commercially, as long as they credit the author for the original creation. You must give appropriate credit, provide a link to the license, and indicate if changes were made. 
was purified by distillation prior to use. The percentage of carbon, hydrogen, nitrogen and sulphur was estimated on elemental analyzer. A digital conductivity meter "Century CC 601" was used to measure the molar conductance of the adducts at room temperature, in dimethylformaamide $\left(10^{-3} \mathrm{M}\right)$. Magnetic susceptibility of the adducts synthesized, were measured at room temperature by VSM method. Infrared spectra of 1:2 addition complexes was recorded on Perkin Elmer FTIR spectrophotometer in the region $4000-400 \mathrm{~cm}^{-1}$. The electronic (UV) spectra was recorded on Systronics 119 UV-visible Spectrophotometer in the range of $12500-40000 \mathrm{~cm}^{-1}$. ESR of adducts was recorded on JES-FA200 ESR spectrometer with $\mathrm{X}$ band. Mass spectra of the compounds was recorded on electron spray ionization mass (ESI-MS) spectrophotometer. Thermogravimetric analysis (TGA/DTA) was carried out on Linseis STA-PT-thermo analyzer. The complex was heated at the rate of $10{ }^{\circ} \mathrm{C} / \mathrm{min}$ in the temperature range of $25-1000{ }^{\circ} \mathrm{C}$.

Preparation of sodium salt of $\boldsymbol{p}$-ethylphenyldithiocarbonate: To a toluene solution of freshly distilled $p$-ethylphenol $(31.7 \mathrm{~mL}, 0.26 \mathrm{~mol})$ was added sodium metal $(0.74 \mathrm{~g}, 0.26$ $\mathrm{mol})$. The contents were refluxed for $3 \mathrm{~h}$ till white precipitates were formed and sodium metal was completely dissolved. Subsequently, to the reaction mixture was added $\mathrm{CS}_{2}(1.95$ $\mathrm{mL}, 0.26 \mathrm{~mol}$ ) at $15^{\circ} \mathrm{C}$ and the contents were stirred for $2-3 \mathrm{~h}$ during which the colour of the mixture changed to yellow. The compound was filtered using alkoxy funnel fitted with G-4 sintered disc. The yellow coloured salt formed was washed with $\mathrm{n}$-hexane and then dried in a vaccum dessicator that gives the compound $p-\mathrm{C}_{2} \mathrm{H}_{5} \mathrm{C}_{6} \mathrm{H}_{4} \mathrm{OCS} \mathrm{S}_{2} \mathrm{Na}$ as pale yellow solid. The reaction is as under:

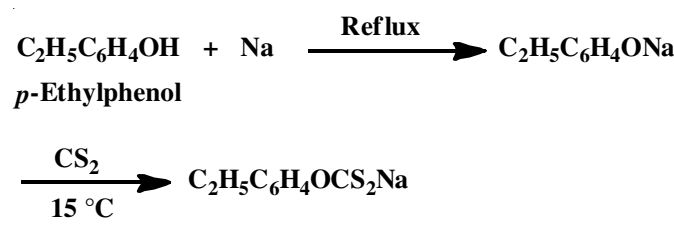

Preparation of adducts of bis ( $p$-ethylphenyldithiocarbonato)copper(II) with ethylpyridines and chloropyridines: The addition complexes of copper(II) were obtained by the direct reaction of methanolic solution of metal salt, sodium salt of $p$-ethylphenyldithiocarbonate and substituted pyridines. A $20 \mathrm{~mL}$ solution of cupric chloride dihydrate $(0.42 \mathrm{~g}, 0.0026$ $\mathrm{mol})$ in methanol was prepared. To this solution, a sodium salt of $p$-ethylphenyldithiocarbonate $(1.14 \mathrm{~g}, 0.0052 \mathrm{~mol})$ and a pyridine molecule $(0.0052 \mathrm{~mol})$ [2-ethylpyridine $=0.59 \mathrm{~g}, 3$ ethylpyridine $=0.59 \mathrm{~g}, 4$-ethylpyridine $=0.59 \mathrm{~g}, 2$-chloropyridine $=0.49 \mathrm{~g}, 3$-chloropyridine $=0.49 \mathrm{~g}]$ dissolved in 40 $\mathrm{mL}$ methanol was slowly added and stirred constantly for $1 \mathrm{~h}$. The precipitates so obtained, were collected on G-4 sintered funnel. The precipitates were washed with methanol followed by drying in vacuum, which yielded the green coloured complex.

Antifungal studies: The antifungal studies of some adducts synthesized were performed by poisoned food technique against the fungal strain Fusarium oxysporium using Potato Dextrose Agar (PDA) as the nutrient medium. The adducts dissolved in DMF were added to nutrient medium. It was then discharged into sterile petri dishes inside the laminar flow and left to solidify. After solidification, the spores of the fungus were suspended

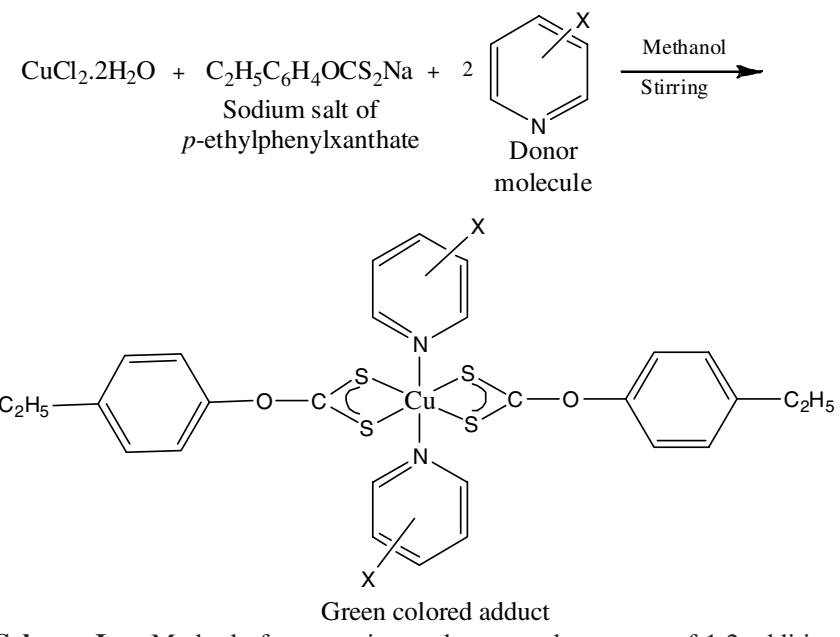

Scheme-I: $\quad$ Method of preparation and proposed structure of 1:2 addition complex of bis(p-ethylphenyldithiocarbonato)copper(II); $\mathrm{X}=$ ethyl $\left(\mathrm{C}_{2} \mathrm{H}_{5}\right)$ or chloro $(\mathrm{Cl})$

using a cork borer (6 $\mathrm{mm}$ in diameter) at the center of petridishes on the PDA medium. The petri dishes were incubated for $96 \mathrm{~h}$ at $27^{\circ} \mathrm{C}$ which were used as control. The radial growth of fungus determines the efficiency of each test sample. The linear fungal growth in controlled manner was measured at various concentrations of the adducts. The formula to calculate the per cent inhibition of the fungus over control is:

$$
\mathrm{I}=\frac{\mathrm{C}-\mathrm{T}}{\mathrm{C}} \times 100
$$

where $\mathrm{I}$ is $\%$ inhibition, $\mathrm{C}$ is the fungal colony diameter in the control plate after the incubation time of $96 \mathrm{~h}$ and $\mathrm{T}$ is the fungal colony diameter in the tested plate after $96 \mathrm{~h}$.

\section{RESULTS AND DISCUSSION}

The addition complexes of bis(p-ethylphenyldithiocarbonato)copper(II) are dark green microcrystalline solids. These are soluble in dimethyl formamide and dimethyl sulfoxide, but are insoluble in acetone, benzene, carbon tetrachloride and ethanol. Elemental analysis showed that the adducts formed have $1: 2$ stoichiometry having the general formula $[\mathrm{Cu}(p-$ $\left.\mathrm{C}_{2} \mathrm{H}_{5} \mathrm{C}_{6} \mathrm{H}_{4} \mathrm{OCS}_{2}\right)_{2} \mathrm{~L}_{2}$ ] [where, $\mathrm{L}=2$-, 3-, 4-ethyl pyridine and 2-, 3-chloro pyridine] (Table-1).

Molar and magnetic measurements: The values of molar conductance of the adducts dissolved in DMF lies in the range $12.81-19.20 \mathrm{ohm}^{-1} \mathrm{~mol}^{-1} \mathrm{~cm}^{2}$ and the range of magnetic moment values of 1:2 complexes of bis(p-ethylphenyldithiocarbonato)copper(II) with ethyl and chloro pyridines is 1.79-1.92 B.M (Table-1). The molar conductance values of adducts prepared in dimethylformaamide are much lower than that for a univalent electrolyte in this solvent indicating the non-electrolytic nature of adducts $[29,30]$. The values of magnetic moment for adducts agrees well with values of magnetic moment reported for the distorted octahedral complexes of copper(II) [31]. These values confirms the paramagnetic nature of adducts.

Infrared spectra: A free dithiocarbonate shows vibrations due to $v(\mathrm{C}-\mathrm{O}-\mathrm{C})$ stretching in the range of $1280-1270 \mathrm{~cm}^{-1}$ and the $v(\mathrm{C}-\mathrm{S})$ stretching vibration exhibits two bands in the range of 1070-1057 $\mathrm{cm}^{-1}$. In the present work, $v(\mathrm{C}-\mathrm{S})$ gives a single sharp band (without a shoulder) of high intensity for 
TABLE-1

MOLAR CONDUCTANCE, MAGNETIC MOMENTS AND ANALYTICAL DATA OF 1:2 ADDITION COMPLEXES OF $B I S(p$-ETHYLPHENYLDITHIOCARBONATO)COPPER(II) WITH SUBSTITUTED PYRIDINES

\begin{tabular}{|c|c|c|c|c|c|c|}
\hline \multirow[t]{2}{*}{ Name of the adduct } & \multicolumn{4}{|c|}{$\begin{array}{l}\text { Elemental analysis }(\%) \text { : } \\
\text { Found (calcd.) }\end{array}$} & \multirow{2}{*}{$\begin{array}{c}\text { Molar } \\
\text { conductance } \\
\left(\mathrm{ohm}^{-1} \mathrm{~mol}^{-1}\right. \\
\left.\mathrm{cm}^{2}\right)\end{array}$} & \multirow{2}{*}{$\begin{array}{c}\mu_{\text {eff }} \\
\text { (B.M.) } \\
298 \mathrm{~K}\end{array}$} \\
\hline & $\mathrm{C}$ & $\mathrm{H}$ & $\mathrm{N}$ & S & & \\
\hline Bis(p-ethylphenyldithiocarbo & $51.2(57.0)$ & $4.1(5.3)$ & $3.8(4.1)$ & $17.9(19.0)$ & 16.20 & 1.80 \\
\hline Bis(p-ethylphenyldithiocarbonato)bis(3-ethylpyridine)copper(II) & $50.4(57.0)$ & $4.0(5.3)$ & $3.6(4.1)$ & $18.2(19.0)$ & 12.81 & 1.79 \\
\hline Bis(p-ethylphenyldithiocarbonato)bis(4-ethylpyridine)copper(II) & $51.7(57.0)$ & $4.5(5.3)$ & $3.6(4.1)$ & $18.4(19.0)$ & 13.66 & 1.83 \\
\hline Bis(p-ethylphenyldithiocarbonato)bis(2-chloropyridine)copper(II) & $39.0(42.8)$ & $3.0(3.3)$ & $3.3(3.5)$ & $15.0(16.3)$ & 18.40 & 1.85 \\
\hline Bis(p-ethylphenyldithiocarbonato)bis(3-chloropyridine)copper(II) & $38.3(42.8)$ & $3.1(3.3)$ & $3.1(3.5)$ & $15.3(16.3)$ & 19.20 & 1.92 \\
\hline
\end{tabular}

the adducts in the range of $1067-1042 \mathrm{~cm}^{-1}$ (Table-2), which suggests symmetrical bidentate binding of dithiocarbonate moiety with copper atom. Moreover, the band for $v(\mathrm{C}-\mathrm{S})$ vibrations in the complexes prepared shifts towards the lower frequency region (higher wavelength) in comparison to free dithiocarbonate ligands, which may also be attributed to symmetrical bidentate binding of dithiocarbonates. On complex formation, the out of plane $\mathrm{C}-\mathrm{H}$ bands shifts towards lower frequency region showing red shift, which confirms that metal ion is attached to the pyridine molecule through its ring nitrogen atom. A band in the region $1260-1224 \mathrm{~cm}^{-1}$ is due to $v(\mathrm{C}-\mathrm{O}-\mathrm{C})$ of dithiocarbonate moiety. A medium to strong intensity band in the range $378-343 \mathrm{~cm}^{-1}$ was observed which may be attributed to $\mathrm{Cu}-\mathrm{S}$ stretching mode [32].

Electronic spectra: The electronic spectra of adducts of bis(p-ethylphenyldithiocarbonato)copper(II) have been obtained in DMF. These adducts of copper(II) showed a broad absorption band appearing at $12585-15395 \mathrm{~cm}^{-1}$, which is assigned to ${ }^{2} \mathrm{E}_{\mathrm{g}} \rightarrow{ }^{2} \mathrm{~T}_{2 \mathrm{~g}}$ transition as expected for six coordinate $d^{9}$ species (Table-2, Figs. 1 and 2). So, a distorted octahedral geometry is suggested for these copper(II) complexes [33,34].

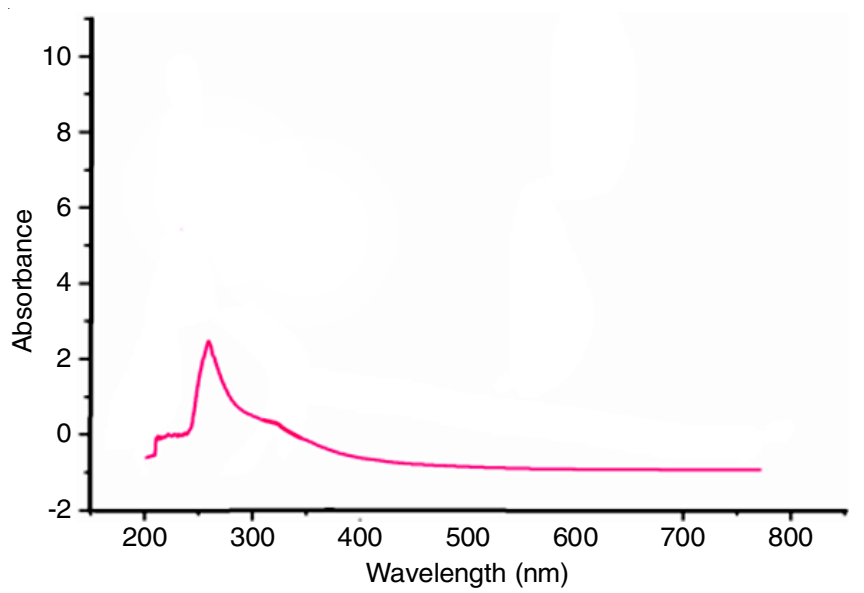

Fig. 1. Electronic spectra of bis(p-ethylphenyldithiocarbonato)bis(2ethylpyridine)copper(II)

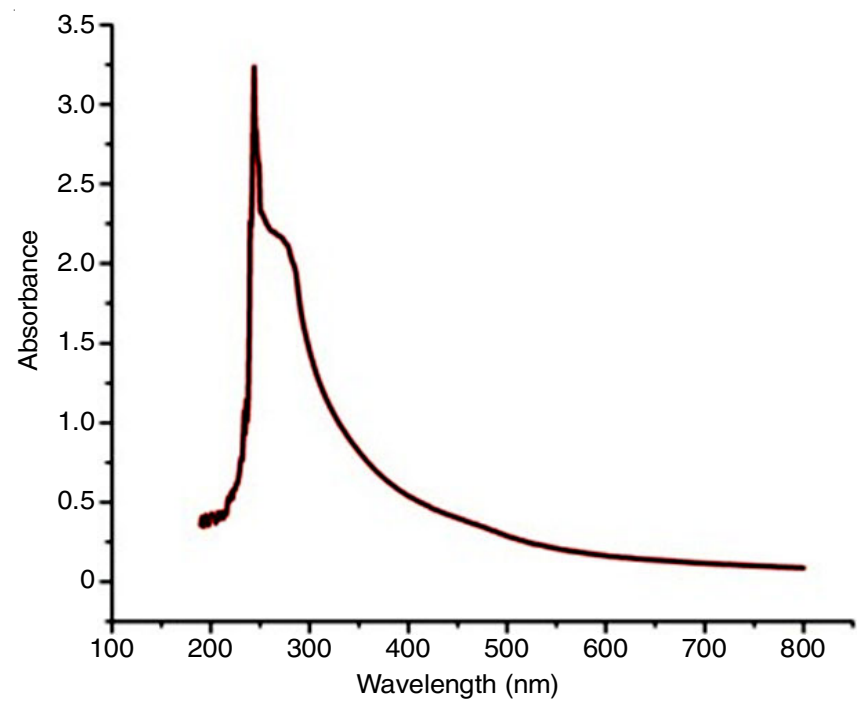

Fig. 2. Electronic spectra of bis(p-ethylphenyldithiocarbonato)bis(2chloropyridine)copper (II)

Electron spin resonance spectra: X-band ESR spectra of all the complexes were recorded in DMF at room temperature. $\mathrm{All} \mathrm{Cu}(\mathrm{II})$ adducts with nitrogen donors exhibits $\mathrm{g}_{\|}$and $\mathrm{g}_{\perp}$ components with axial symmetry. The complex $[\mathrm{Cu}(p-$ $\left.\left.\mathrm{C}_{2} \mathrm{H}_{5} \mathrm{C}_{6} \mathrm{H}_{4} \mathrm{OCS}_{2}\right)_{2}\left(\mathrm{C}_{7} \mathrm{H}_{9} \mathrm{~N}\right)_{2}\right]$ exhibits $\mathrm{g}_{\|}=2.250, \mathrm{~g}_{\perp}=2.034$ and $\mathrm{g}_{\|}=2.181, \mathrm{~g}_{\perp}=2.042$ for the complex $\left[\mathrm{Cu}\left(p-\mathrm{C}_{2} \mathrm{H}_{5} \mathrm{C}_{6} \mathrm{H}_{4} \mathrm{OCS}_{2}\right)_{2}\right.$ $\left(\mathrm{C}_{5} \mathrm{H}_{4} \mathrm{NCl}\right)_{2}$ ] (Fig. 3).

In ESR spectra of the synthesized adducts, $g_{\|}>g_{\perp}$ which indicates a slight elongation along $z$-axis thus, representing elongated axial symmetry of the coor-dination sphere around $\mathrm{Cu}(\mathrm{II})$ ion. Here, $\mathrm{g}_{\|}>\mathrm{g}_{\perp}>2.0023$ shows substantial parallel hyperfine splitting and the ground state is $\mathrm{d}_{\mathrm{x}^{2}-\mathrm{y}^{2}}$ [35].

Mass spectra: The mass spectra of the adducts of bis(pethylphenyldithiocarbonato)copper(II) with ethylpyridines and chloropyridines was recorded. The mass spectra of the complex $\mathrm{Cu}\left(\mathrm{S}_{2} \mathrm{COC}_{6} \mathrm{H}_{4} \mathrm{C}_{2} \mathrm{H}_{5}\right)_{2}$ (3-chloropyridine) $)_{2}$ showed a weak molecular ion peak at $m / z 684.5$ (Fig. 4). The occurance of molecular ion peak $[\mathrm{M}]^{+}$at this value indicates that the comp-

\begin{tabular}{|c|c|c|c|c|c|c|}
\hline \multirow{3}{*}{ Name of the adduct } & \multicolumn{5}{|c|}{$\begin{array}{l}\text { TABLE- } 2 \\
\text { TA OF } 1: 2 \text { ADDITION COMPLEXES OF } \\
\text { ATO)COPPER(II) WITH SUBSTITUTED PYRIDINES }\end{array}$} & \multirow{3}{*}{$v(\mathrm{Cu}-\mathrm{S})$} \\
\hline & \multirow{2}{*}{$\begin{array}{l}v\left(\mathrm{~cm}^{-1}\right) \\
\left(\mathrm{e}_{\mathrm{g}} \rightarrow \mathrm{t}_{2 \mathrm{~g}}\right)\end{array}$} & \multirow{2}{*}{$v(\mathrm{C}-\mathrm{S})$} & \multirow{2}{*}{$\mathrm{v}(\mathrm{C}-\mathrm{O}-\mathrm{C})$} & \multicolumn{2}{|c|}{ Aromatic stretching } & \\
\hline & & & & $v(\mathrm{C}-\mathrm{H})$ & $v(\mathrm{C}-\mathrm{C})$ & \\
\hline Bis(p-ethylphenyldithiocarbonato)bis(2-ethylpyridine)copper(II) & 13587 & 1055 & 1242 & 3030 & 1594 & 354 \\
\hline Bis(p-ethylphenyldithiocarbonato)bis(3-ethylpyridine)copper(II) & 12890 & 1042 & 1250 & 3024 & 1596 & 357 \\
\hline Bis(p-ethylphenyldithiocarbonato)bis(4-ethylpyridine)copper(II) & 12585 & 1067 & 1230 & 3046 & 1601 & 343 \\
\hline Bis(p-ethylphenyldithiocarbonato)bis(2-chloropyridine)copper(II) & 14489 & 1060 & 1224 & 3026 & 1597 & 378 \\
\hline Bis(p-ethylphenyldithiocarbonato)bis(3-chloropyridine)copper(II) & 15395 & 1051 & 1247 & 3041 & 1599 & 361 \\
\hline
\end{tabular}




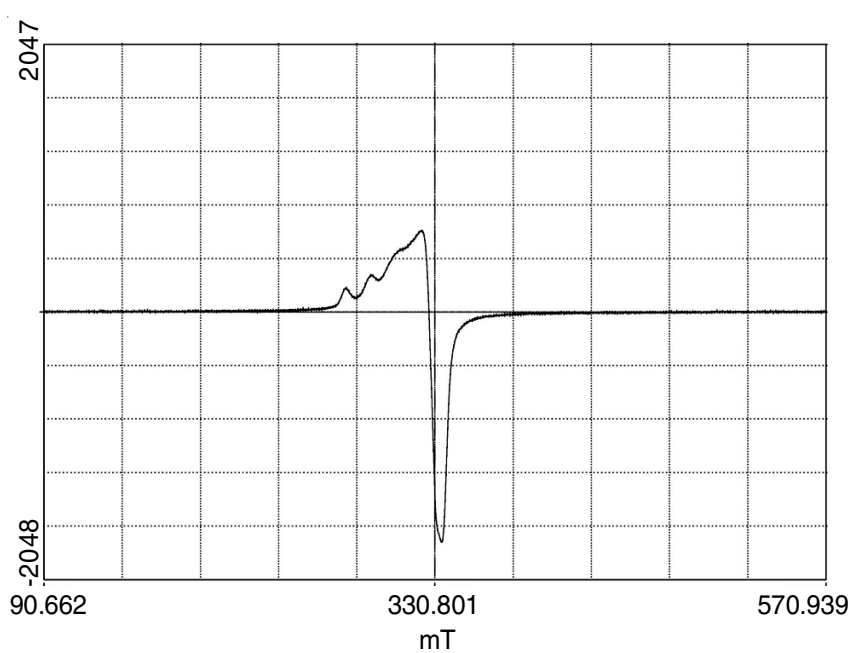

Fig. 3. ESR spectra of bis(p-ethylphenyldithiocarbonato)bis(2-ethylpyridine)copper(II)

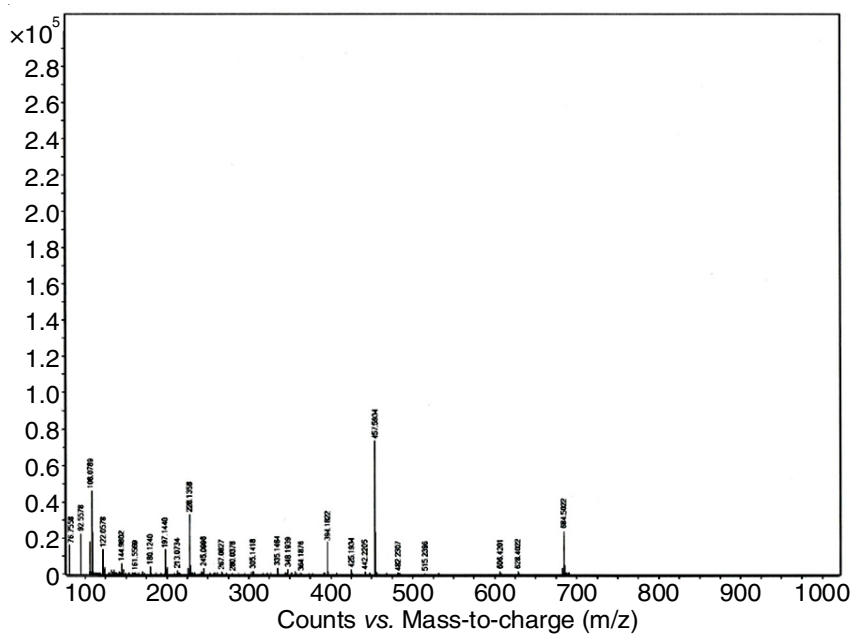

Fig. 4. Mass spectra of bis ( $p$-ethylphenyldithiocarbonato) bis(3-chloropyridine)copper(II) $(\mathrm{m} / \mathrm{z}=684.5)$

lexes formed are monomeric. The base peak for this complex appeared at $\mathrm{m} / \mathrm{z} 457.5$ which corresponds to the fragment $\left[\mathrm{Cu}\left(\mathrm{S}_{2} \mathrm{COC}_{6} \mathrm{H}_{4} \mathrm{C}_{2} \mathrm{H}_{5}\right)_{2}\right]^{+}$. It suggests the formation of copper(I) xanthate as the most stable fragment in the mass spectral studies of the adducts of $\mathrm{Cu}$ (II).

${ }^{1} \mathrm{H}$ NMR: The ${ }^{1} \mathrm{H}$ NMR spectra of these addition complexes in deuterated DMSO gave characteristic proton resonances.
In this spectra, the signals for $-\mathrm{CH}_{2} \mathrm{CH}_{3}$ (ethyl group) on the benzene ring were observed at $1.26 \mathrm{ppm}$ as triplet (for $-\mathrm{CH}_{3}$ ) and at $2.63 \mathrm{ppm}$ as quartet (for $-\mathrm{CH}_{2}$ ). The protons of $\mathrm{C}_{6} \mathrm{H}_{4}$ in the copper(II) complexes gave signals with splitting in the range 6.82-7.10 ppm. The ring protons of para complexes give two resonances. In case of ethylpyridines and chloropyridines, the protons of pyridine ring gave signals in the range 7.16$8.49 \mathrm{ppm}$ and ethyl group absorbs at $0.98 \mathrm{ppm}$ as triplet $\left(-\mathrm{CH}_{3}\right)$ and at $2.76 \mathrm{ppm}$ as quartet $\left(-\mathrm{CH}_{2}\right)($ Table-3).

${ }^{13} \mathrm{C}$ NMR: ${ }^{13} \mathrm{C}$ NMR of the addition complexes exhibited chemical shifts for all carbons in their characteristic regions. The signal for ethyl group occurred at $14.27 \mathrm{ppm}$ (for $-\mathrm{CH}_{3}$ ) and at $28.35 \mathrm{ppm}$ (for $-\mathrm{CH}_{2}$ ). The carbon nuclei of phenyl group $\left(\mathrm{C}_{6} \mathrm{H}_{4}\right)$ gave the resonance in the region 114.03-130.89 $\mathrm{ppm}$. The carbon attached to the ethyl group appeared at 122.70-134.50 ppm. The ethylphenyl derivatives gave signal in the region 151.30-152.99 ppm. The chemical shift for the carbon nuclei of dithiocarbonate moiety $\left(-\mathrm{OCS}_{2}\right)$ was observed at $166.95-185.68 \mathrm{ppm}$, shifting it upfield (30-36 ppm) in comparison with the parent ligand. The aryl carbon nuclei of the pyridines show three resonances in the region 123.34-151.83 ppm (Table-4).

Thermogravimetric analysis: The TG of the complex [bis(p-ethylphenyldithiocarbonato) bis(2-ethylpyridine)copper(II)] i.e., $\left[\mathrm{Cu}\left(p-\mathrm{C}_{2} \mathrm{H}_{5} \mathrm{C}_{6} \mathrm{H}_{4} \mathrm{OCS}_{2}\right)_{2}\left(\mathrm{C}_{7} \mathrm{H}_{9} \mathrm{~N}\right)_{2}\right]$ showed an initial weight loss of $34.82 \%$ (calculated $=32.08 \%$ ) at 394.5 ${ }^{\circ} \mathrm{C}$ by loosing two molecules of 2-ethylpyridine. On further heating, a weight loss of $62 \%$ (calculated $=62.2 \%$ ) at 661.8 ${ }^{\circ} \mathrm{C}$ due to the loss of two xanthate moieties was observed. The gradual loss in weight gave a stable sulphide, $\mathrm{CuS}$ at $900{ }^{\circ} \mathrm{C}$ (Fig. 5).

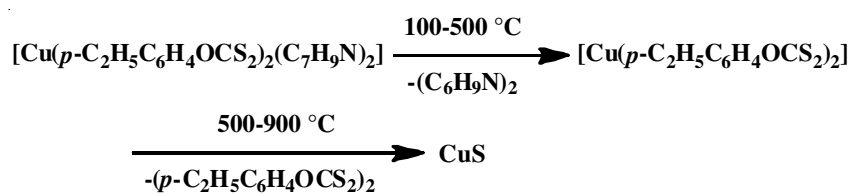

The TG of [bis(p-ethylphenyldithiocarbonato)bis(2chloropyridine)copper(II)] i.e., $\left[\mathrm{Cu}\left(p-\mathrm{C}_{2} \mathrm{H}_{5} \mathrm{C}_{6} \mathrm{H}_{4} \mathrm{OCS}_{2}\right)_{2}\left(\mathrm{C}_{5} \mathrm{H}_{4} \mathrm{NCl}\right)_{2}\right]$ showed an initial weight loss of $32.2 \%$ on heating (calculated $=33 \%$ ) at $531.4{ }^{\circ} \mathrm{C}$ due to the loss of two molecules of 2-chloropyridine. Further heating of complex results in the weight loss of $57.2 \%$ (calculated $=57.5 \%$ ) at $874.4{ }^{\circ} \mathrm{C}$ by loosing

\begin{tabular}{|c|c|c|}
\hline \multicolumn{3}{|c|}{$\begin{array}{c}\text { TABLE-3 } \\
{ }^{1} \text { H NMR SPECTRAL DATA OF 1:2 ADDUCTS OF } \\
B I S(p \text {-ETHYLPHENYLDITHIOCARBONATO)COPPER(II) WITH SUBSTITUTED PYRIDINES }\end{array}$} \\
\hline$-\mathrm{CH}_{2}-\mathrm{CH}_{3}$ & $\begin{array}{l}{ }^{1} \mathrm{H} \mathrm{NMR} \text { of } \mathrm{C}_{6} \mathrm{H}_{4} \\
4 \\
4\end{array}$ & Donor moiety \\
\hline $1.26, \mathrm{t}, 6 \mathrm{H}\left(\mathrm{CH}_{3}\right) ; 2.63, \mathrm{~m}, 4 \mathrm{H}\left(\mathrm{CH}_{2}\right)$ & $6.92, \mathrm{~d}, 4 \mathrm{H},\left[\mathrm{H}_{(1,5)}\right] ; 6.83, \mathrm{~d}, 4 \mathrm{H},\left[\mathrm{H}_{(2,4)}\right]$ & $\begin{array}{l}\text { 7.19-8.40, m, 8H, }\left(\mathrm{NC}_{5} \mathrm{H}_{4}\right) ; 0.97, \mathrm{t}, 6 \mathrm{H},\left(\mathrm{CH}_{3}\right) ; 2.76, \mathrm{~m} \text {, } \\
4 \mathrm{H},\left(\mathrm{CH}_{2}\right)\end{array}$ \\
\hline $1.28, \mathrm{t}, 6 \mathrm{H},\left(\mathrm{CH}_{3}\right) ; 2.62, \mathrm{~m}, 4 \mathrm{H}\left(\mathrm{CH}_{2}\right)$ & $7.10, \mathrm{~d}, 4 \mathrm{H},\left[\mathrm{H}_{(1,5)}\right] ; 6.80, \mathrm{~d}, 4 \mathrm{H},\left[\mathrm{H}_{(2,4)}\right]$ & $\begin{array}{l}\text { 7.22-8.39, m, } 8 \mathrm{H}\left(\mathrm{NC}_{5} \mathrm{H}_{4}\right) ; 1.20, \mathrm{t}, 6 \mathrm{H}\left(\mathrm{CH}_{3}\right) ; 2.67, \mathrm{~m}, \\
4 \mathrm{H},\left(\mathrm{CH}_{2}\right)\end{array}$ \\
\hline $1.26, \mathrm{t}, 6 \mathrm{H}\left(\mathrm{CH}_{3}\right) ; 2.61, \mathrm{~m}, 4 \mathrm{H}\left(\mathrm{CH}_{2}\right)$ & $6.98, \mathrm{~d}, 4 \mathrm{H},\left[\mathrm{H}_{(1,5)}\right] ; 6.72, \mathrm{~d}, 4 \mathrm{H},\left[\mathrm{H}_{(2,4)}\right]$ & $\begin{array}{l}\text { 7.31-8.41, m, 8H, }\left(\mathrm{NC}_{5} \mathrm{H}_{4}\right) ; 0.99, \mathrm{t}, 6 \mathrm{H}\left(\mathrm{CH}_{3}\right) ; 2.74, \mathrm{~m} \text {, } \\
4 \mathrm{H}\left(\mathrm{CH}_{2}\right)\end{array}$ \\
\hline $1.25, \mathrm{t}, 6 \mathrm{H}\left(\mathrm{CH}_{3}\right) ; 2.63, \mathrm{~m}, 4 \mathrm{H}\left(\mathrm{CH}_{2}\right)$ & $7.08, \mathrm{~d}, 4 \mathrm{H},\left[\mathrm{H}_{(1,5)}\right] ; 6.87, \mathrm{~d}, 4 \mathrm{H},\left[\mathrm{H}_{(2,4)}\right]$ & $7.45-8.41, \mathrm{~m}, 8 \mathrm{H}\left(\mathrm{NC}_{5} \mathrm{H}_{4}\right)$ \\
\hline $1.27, \mathrm{t}, 6 \mathrm{H}\left(\mathrm{CH}_{3}\right) ; 2.63, \mathrm{~m}, 4 \mathrm{H}\left(\mathrm{CH}_{2}\right)$ & $6.90, \mathrm{~d}, 4 \mathrm{H},\left[\mathrm{H}_{(1,5)}\right] ; 6.72, \mathrm{~d}, 4 \mathrm{H},\left[\mathrm{H}_{(2,4)}\right]$ & 7.32-8.49, m, 8H $\left(\mathrm{NC}_{5} \mathrm{H}_{4}\right)$ \\
\hline
\end{tabular}




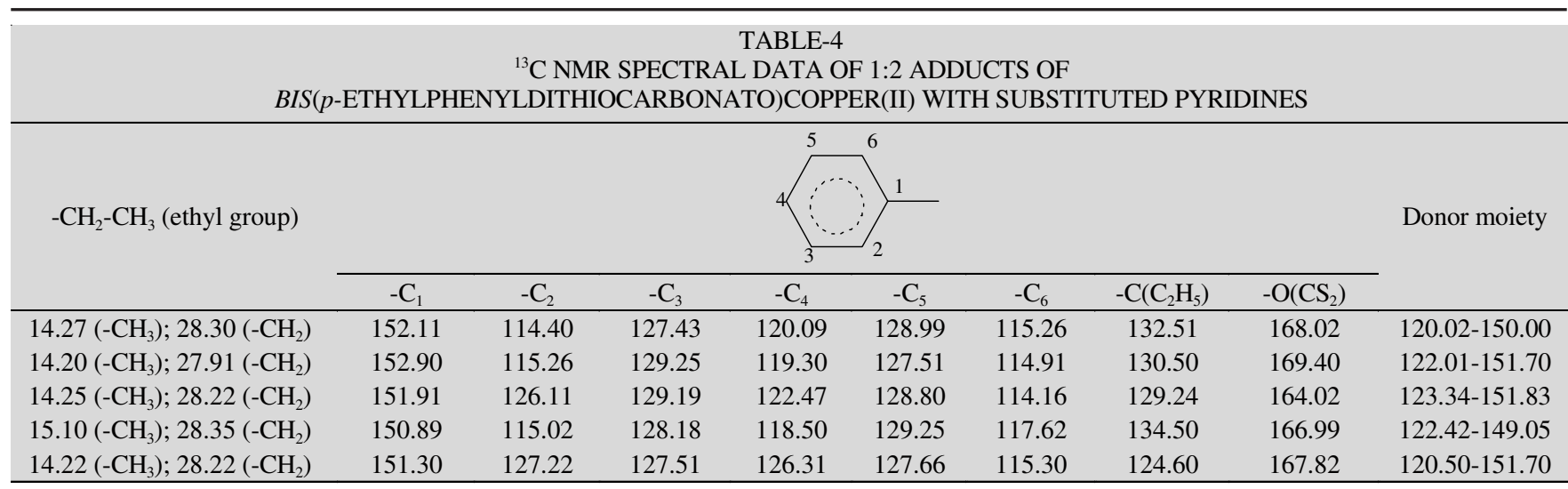

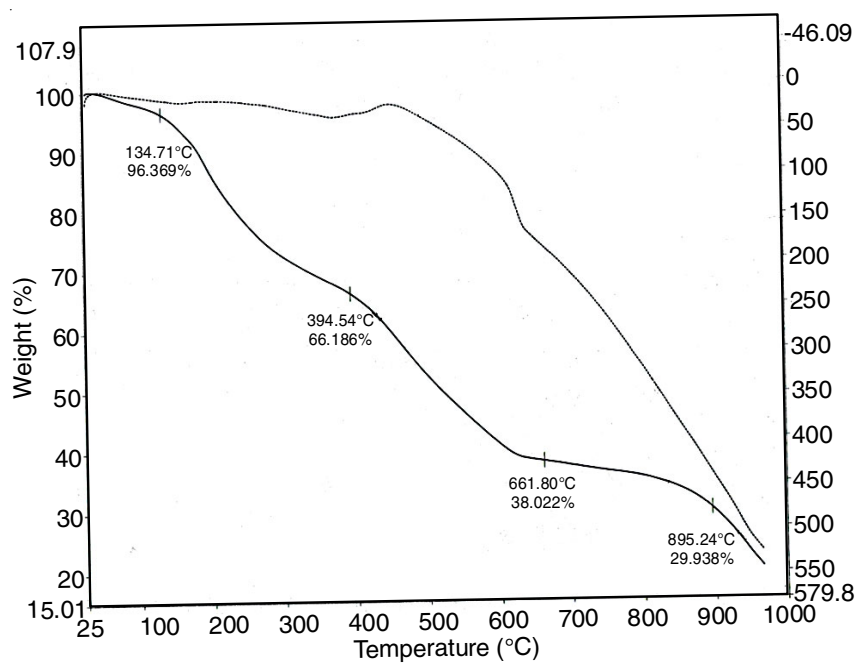

Fig. 5. Thermal curve of bis(p-ethylphenyldithiocarbonato)bis(2-ethylpyridine)copper(II)

two xanthate molecules. The gradual loss in weight results in the formation of a stable sulphide at $910^{\circ} \mathrm{C}$.

$$
\begin{aligned}
& {\left[\mathrm{Cu}\left(p-\mathrm{C}_{2} \mathrm{H}_{5} \mathrm{C}_{6} \mathrm{H}_{4} \mathrm{OCS}_{2}\right)_{2}\left(\mathrm{C}_{5} \mathrm{H}_{4} \mathrm{NCl}\right)_{2}\right] \stackrel{100-600}{\stackrel{\circ}{ } \mathrm{C}} \underset{-\left(\mathrm{C}_{5} \mathrm{H}_{4} \mathrm{NCl}\right)_{2}}{\longrightarrow}-\left[\mathrm{Cu}\left(p-\mathrm{C}_{2} \mathrm{H}_{5} \mathrm{C}_{6} \mathrm{H}_{4} \mathrm{OCS}_{2}\right)_{2}\right]} \\
& \underset{\left.-\left(p-\mathrm{C}_{2} \mathrm{H}_{5} \mathrm{C}_{6} \mathrm{H}_{4} \mathrm{OCS}_{2}\right)_{2}\right)}{\stackrel{600-910}{\longrightarrow} \mathrm{C}} \mathrm{CuS}
\end{aligned}
$$

Therefore, the result agrees well with the composition of adducts. The calculated mass change agrees favourably with experimental values.

Antifungal Activity: The complex (c) $\left[\mathrm{Cu}\left(p-\mathrm{C}_{2} \mathrm{H}_{5} \mathrm{C}_{6} \mathrm{H}_{4} \mathrm{OCS}_{2}\right)_{2}\right.$ $\left(\mathrm{C}_{7} \mathrm{H}_{9} \mathrm{~N}\right)_{2}$ ] exhibited enhanced antifungal activity than complex (a) and (b). The data for antifungal studies is reported in Table5 , which provides two remarkable results. First, there is an inverse relationship between the concentration of the complex and the colony diameter of the fungus, which means that on increasing the complex concentration, the fungal colony diameter decreases (increase in per cent inhibition of fungus) i.e., the adducts showed enhanced antifungal activity. Second, the greater antifungal activity has been observed in the complexes having donor molecules than the complexes without donor molecules. This enhanced activity is due to the reason that metal complexes diffuse through the cell membrane, disturbing the respiration process of the cell and blocking the formation of proteins that inhibits the fungus growth. This can be more clearly explained in the light of Overtone's concept and

\begin{tabular}{|c|c|c|c|}
\hline \multicolumn{4}{|c|}{$\begin{array}{c}\text { TABLE-5 } \\
\text { IN VITRO ANTIFUNGAL ACTIVITY OF 1:2 COMPLEXES } \\
\text { OF BIS( } p \text {-ETHYLPHENYLDITHIOCARBONATO) } \\
\text { COPPER(II) WITH SUBSTITUTED PYRIDINES }\end{array}$} \\
\hline $\begin{array}{l}\text { Name of } \\
\text { sample* }\end{array}$ & $\begin{array}{c}\text { Concentration } \\
(\mathrm{ppm})\end{array}$ & $\begin{array}{l}\text { Colony diameter } \\
\text { (T) }(\mathrm{mm})\end{array}$ & Inhibition (\%) \\
\hline \multirow{5}{*}{ A } & 50 & 90 & 0 \\
\hline & 100 & 78.7 & 12.5 \\
\hline & 150 & 73.4 & 18.4 \\
\hline & 200 & 68.1 & 24.3 \\
\hline & 250 & 56.6 & 37.1 \\
\hline \multirow{5}{*}{ B } & 50 & 74.3 & 17.4 \\
\hline & 100 & 58.0 & 35.5 \\
\hline & 150 & 47.3 & 47.4 \\
\hline & 200 & 40.2 & 55.3 \\
\hline & 250 & 34.0 & 62.2 \\
\hline \multirow{5}{*}{$\mathrm{C}$} & 50 & 69.7 & 22.5 \\
\hline & 100 & 50.1 & 44.3 \\
\hline & 150 & 38.5 & 57.2 \\
\hline & 200 & 31.7 & 64.7 \\
\hline & 250 & 26.5 & 70.5 \\
\hline
\end{tabular}
Tweedy's chelation theory [36].

\section{Conclusion}

To conclude, the study confirms the formation of copper(II) dithiocarbonate adducts with nitrogen donor ligands as indicated from elemental analysis, molar measurements, magnetic measurements, spectral analysis and TGA. So, it is proposed that $\mathrm{Cu}$ (II) ion has a distorted octahedral coordination with elongated axial symmetry of ligands around it.

\section{ACKNOWLEDGEMENTS}

The authors are grateful to IIIM-CSIR, Jammu, SAIFIIT- Bombay and SKUAST-Jammu, India for providing the technical support.

\section{CONFLICT OF INTEREST}

The authors declare that there is no conflict of interests regarding the publication of this article.

\section{REFERENCES}

1. S. Ghoshal and V.K. Jain, J. Chem. Sci., 119, 583 (2007); https://doi.org/10.1007/s12039-007-0073-x.

2. H.W. Chen and J.P. Fackler, Inorg. Chem., 17, 22 (1978); https://doi.org/10.1021/ic50179a006. 
3. J.P. Fackler Jr., D.P. Schussler and H.W. Chen, Synth. Inorg. Met.-Org. Chem., 8, 27 (1978); https://doi.org/10.1080/00945717808057383.

4. R.F. Semeniuc, T.J. Reamer, J.P. Blitz, K.A. Wheeler and M.D. Smith, Inorg. Chem., 49, 2624 (2010); https://doi.org/10.1021/ic901551t.

5. S. Andotra, N. Kalgotra and S.K. Pandey, Bioinorg. Chem. Appl., 2014, 1 (2014); https://doi.org/10.1155/2014/780631.

6. O.V. Bakbardina, I.Y. Pukhnyarskaya, M.A. Gazalieva, S.D. Fazylov and E.M. Makarov, Russ. J. Appl. Chem., 79, 1726 (2006); https://doi.org/10.1134/S1070427206100375.

7. A.A. Abramov and K.S.E. Forssberg, Miner. Process. Extr. Metall. Rev., 26, 77 (2005); https://doi.org/10.1080/08827500590883197.

8. S. Chaudhari and V. Tare, J. Appl. Polym. Sci., 71, 1325 (1999); https://doi.org/10.1002/(SICI)1097-4628(19990222)71:8<1325::AIDAPP12>3.0.CO;2-F.

9. G. Winter, Rev. Inorg. Chem., 2, 253 (1980).

10. R.P. Burns, F.P. Mccullough and C.A. Mcauliffe, Adv. Inorg. Chem. Radiochem., 23, 211 (1980); https://doi.org/10.1016/S0065-2792(08)60094-1.

11. E.R.T. Tiekink and G. Winter, Rev. Inorg. Chem., 12, 183 (1992); https://doi.org/10.1515/REVIC.1992.12.3-4.183.

12. B.F. Hoskins and C.D. Pannan, J. Chem. Soc. Chem. Commun., 11, 408 (1975); https://doi.org/10.1039/c39750000408.

13. D. Dakternieks, R. Di Giacomo, R.W. Gable and B.F. Hoskins, J. Am. Chem. Soc., 110, 6762 (1988); https://doi.org/10.1021/ja00228a026.

14. K. Xu and W. Ding, Mater. Lett., 62, 4437 (2008); https://doi.org/10.1016/j.matlet.2008.07.040.

15. L.I. Victoriano and H.B. Cortes, J. Coord. Chem., 39, 231 (1996); https://doi.org/10.1080/00958979608024331.

16. M. Scendo, Corros. Sci., 47, 1738 (2005); https://doi.org/10.1016/j.corsci.2004.08.015.

17. W.J. Orts, R.E. Sojka and G.M. Glenn, Agro Food Ind. Hi-Tech, 13, 37 (2002).

18. A.O. Gorgulu, M. Arslan and E. Cil, J. Coord. Chem., 59, 637 (2006); https://doi.org/10.1080/00958970500393356.

19. A.C. Larsson and S. Oberg, J. Phys. Chem. A, 115, 1396 (2011); https://doi.org/10.1021/jp110233d.
20. E. Amtmann, Drugs Exp. Clin. Res., 22, 287 (1996).

21. M. Perluigi, G. Joshi, R. Sultana, V. Calabrese, C. De Marco, R. Coccia and D.A. Butterfield, Neurosci., 138, 1161 (2006); https://doi.org/10.1016/j.neuroscience.2005.12.004.

22. G. Crisponi, V.M. Nurchi, D. Fanni, C. Gerosa, S. Nemolato and G. Faa, Coord. Chem. Rev., 254, 876 (2010); https://doi.org/10.1016/j.ccr.2009.12.018.

23. J.A. Drewry and P.T. Gunning, Coord. Chem. Rev., 255, 459 (2011); https://doi.org/10.1016/j.ccr.2010.10.018.

24. M.E. Katsarou, E.K. Efthimiadou, G. Psomas, A. Karaliota and D. Vourloumis, J. Med. Chem., 51, 470 (2008); https://doi.org/10.1021/jm7013259.

25. E.K. Efthimiadou, H. Thomadaki, Y. Sanakis, C.P. Raptopoulou, N. Katsaros, A. Scorilas, A. Karaliota and G. Psomas, J. Inorg. Biochem., 101, 64 (2007); https://doi.org/10.1016/j.jinorgbio.2006.07.019.

26. F. Dimiza, S. Fountoulaki, A.N. Papadopoulos, C.A. Kontogiorgis, V. Tangoulis, C.P. Raptopoulou, V. Psycharis, A. Terzis, D.P. Kessissoglou and G. Psomas, Dalton Trans., 40, 8555 (2011); https://doi.org/10.1039/c1dt10714c.

27. F. Dimiza, F. Perdih, V. Tangoulis, I. Turel, D.P. Kessissoglou and G. Psomas, J. Inorg. Biochem., 105, 476 (2011); https://doi.org/10.1016/j.jinorgbio.2010.08.013.

28. B. Gupta, N. Kalgotra, S. Andotra and S.K. Pandey, Monatsh. Chem., 143, 1087 (2012); https://doi.org/10.1007/s00706-011-0704-2.

29. R.L. Martin and A. Whitley, J. Chem. Soc., 13, 1394 (1958); https://doi.org/10.1039/jr9580001394.

30. W.J. Geary, Coord. Chem. Rev., 7, 81 (1971); https://doi.org/10.1016/S0010-8545(00)80009-0.

31. C. Spinu and A. Kriza, Acta Chim. Slov., 47, 179 (2000).

32. N. Singh and A. Prasad, Indian J. Chem., 47A, 650 (2008).

33. G. Kumar, A. Kumar, N. Shishodia, Y.P. Garg and B.P. Yadav, E-J. Chem., 8, 1872 (2011); https://doi.org/10.1155/2011/497279.

34. G.S. Kurdekar, S. Mudigoudar Puttanagouda, N.V. Kulkarni, S. Budagumpi and V.K. Revankar, Med. Chem. Res., 20, 421 (2011); https://doi.org/10.1007/s00044-010-9330-5.

35. R.A. Ahmadi, F. Hasanvand, G. Bruno, H.A. Rudbari and S. Amani, ISRN Inorg. Chem., 2013, 426712 (2013); https://doi.org/10.1155/2013/426712.

36. B.G. Tweedy and C. Loeppky, Phytopathology, 58, 1522 (1968). 